\title{
Proposal of a New Serological Group ("V") of Hemolytic Streptococci Isolated from Swine Lymph Nodes
}

\author{
J. JELÍNKOVA and V. KUBÍN
}

\begin{abstract}
Department of Medical Microbiology, Postgraduate Medical and Pharmaceutical Institute and WHO International Reference Center for Streptococcus Typing, and Laboratory of Otolaryngology, Czechoslovak Academy of Sciences, Prague, Czechoslovakia
\end{abstract}

\begin{abstract}
During a bacteriological examination of materials from slaughtered swine, we isolated from hemorrhagic and markedly edematous mandibular lymph nodes strains of hemolytic streptococci belonging to groups $\mathrm{C}, \mathrm{E}, \mathrm{L}, \mathrm{S}$, and $\mathrm{U}$; also isolated were beta-hemolytic strains that were not classifiable within any of the known serological groups A to U. Hyperimmune sera prepared with these strains contain antibodies that are specific in the homologous system only and are distinct from antibodies against group $A$ to $U$ strains. The strains were investigated for their biochemical and physiological properties. On the basis of the characters determined and because of repeated isolations made in different localities, it is proposed that the strains are representatives of a new serological group of hemolytic streptococci, for which we propose the designation "V."
\end{abstract}

While classifying some strains of hemolytic streptococci isolated during 1967 to 1974 from the lymph nodes of slaughtered swine, we repeatedly encountered isolates that did not belong either in the "classical" serological groups $A$ to $U$ or the more recently described groups $\mathrm{R}, \mathrm{S}, \mathrm{T}(2)$, and $\mathrm{U}(3,14,15)$. Since the physiological and biochemical characters of these strains also did not correspond to those of the "groupable" hemolytic streptococci, the strains were subjected to a closer immunological study, which confirmed their distinction.

In May 1973, the representative strains and homologous antisera were submitted to the Taxonomic Subcommittee on Streptococci and Pneumococci of the International Committee on Systematic Bacteriology (IAMS) for consideration and recommendation of any further procedure necessary for deciding whether the candidate strains belonged to a new serological group.

The group "V" strains no. 169 and 176 and the homologous antisera were reexamined in the laboratories of W. R. Maxted (London), R. R. Facklam (Atlanta, Ga.), and E. Thal (Stockholm). The antiserum was considered specific since it did not cross-react with any of the group $A$ to $U$ reference antigens. No reactivity was found between the candidate strains and reference grouping sera. Positive precipitation was found in the homologous system only. The serological difference of the strains was confirmed.

\section{MATERIALS AND METHODS}

Bacterial strains. "Ungroupable" beta hemolytic Streptococcus strains no. 169 and 176 were isolated in February 1968; strain no. 100552 was isolated in January 1974 from hemorrhagic swine lymph nodes. Group identification was performed with the reference Streptococcus group A to U strains maintained at the Czechoslovak National Collection of Type Cultures (Table 1).

Serological grouping. Serological grouping was performed by the precipitation reaction in capillary tubes and in the ring-test arrangement. Extracts were prepared by the method of Lancefield (7) and Fuller (5). Rabbit hyperimmune grouping sera $A$ to $U$ were prepared with heat-killed whole streptococcus cells (13), using the reference group strains listed in Table 1 , at the WHO International Center for Streptococcus Typing, Prague, Czechoslovakia.

Susceptibility of the group antigen to enzymes. Samples $(0.3 \mathrm{ml})$ of extracts (acid-heat) were treated with trypsin and pepsin, using the technique previously described by Wilkinson (16).

Absorption experiments. A mixture of 3 volumes of serum and 1 volume of packed heat-killed cells was incubated at $37 \mathrm{C}$ in a water bath for $30 \mathrm{~min}$, using the strains listed in Table 1.

Biochemical and physiological properties. Biochemical and physiological properties were tested by the method used by Colman (G. Colman, Ph.D. Thesis, University of London, London, 1970), Facklam (4), Hahn (6), and Raška and Rotta (12).

\section{RESULTS AND DISCUSSION}

Strains no. 169,176 , and 100552 are gram-positive cocci arranged in chains and 
TABLE 1. Reference streptococcus group strains used for group identification ${ }^{a}$

\begin{tabular}{ll}
\hline Group & \multicolumn{1}{c}{ Strain } \\
\hline A & J17A4 Lancefield \\
B & 090R variant Lancefield \\
C & Chestle Maxted \\
D & NCTC 8307 Maxted \\
E & K 131 Maxted \\
F & O'Mahoney Maxted \\
G & Valente Maxted \\
H & Blackburn Maxted \\
K & Charwoman Lancefield \\
L & SHC 16 Fry \\
M & SHC 256 Maxted \\
N & J. O. Lactis Maxted \\
O & B 357 Wiley \\
P & 54/853 Maxted \\
Q & E 6844 Maxted \\
R & Maxted \\
S & Maxted \\
T & de Moor \\
U & IV 87 Thal \\
\hline
\end{tabular}

${ }^{a}$ Maintained at the Czechoslovak National Collection of Type Cultures

producing beta hemolysis on blood agar plates containing sheep, human, or rabbit red cells. The CAMP test is positive (1) for these strains. (The CAMP reaction is widely used as a screening test for group B streptococci, Streptococcus agalactiae [1]. However, the specificity of the test is limited by findings of some CAMP-positive strains belonging to certain other groups of species [P, U, and possibly group $\mathrm{R}$ and Streptococcus uberis]. Whether CAMP test positivity is a typical and regular characteristic of the new group of streptococci here proposed remains to be shown by the examination of a larger number of these strains, isolated not only at different times but also from different localities and possibly different kinds of material.)

Biochemical and physiological characters. The following tests and reactions were performed with a positive reaction: growth in methyleneblue milk; growth in $4.0 \%$ and $2.0 \% \mathrm{NaCl}$ broth; production of ammonia from arginine; production of acid from trehalose, lactose, glucose, sucrose, sorbitol, mannitol, and salicin.

The following tests and reactions resulted in a negative reaction: production of catalase; growth on $40 \%$ and $10 \%$ bile, at $10 \mathrm{C}$ and $45 \mathrm{C}$; growth in $\mathrm{pH} 9.6$ broth; resistance to $60 \mathrm{C}$ for $30 \mathrm{~min}$ and to $0.04 \%$ tellurite; reduction of $0.1 \%$ tetrazolium; hydrolysis of starch and hippurate; production of acid from esculin, arabinose, inulin, melezitose, melibiose, dulci- tol, and glycerol; and production of polysaccharide from sucrose brnth.

The following tests and reactions had variable results: growth in $6.5 \% \mathrm{NaCl}$; acid from raffinose.

Thus, some biochemical and physiological characters of strains no. 169, 176, and 100552 differentiate them from other hemolytic streptococcus groups and species $(4,6,12 ; \mathrm{G}$. Colman, Ph.D. thesis). The isolates most closely resemble group E, $P$, and $U$ strains. The following characters could be of some differential diagnostic value: positive growth in $4 \%$ $\mathrm{NaCl}$ broth, negative esculin fermentation, and negative hippurate hydrolysis.

Antigenic studies and immunization experiments. Group extracts of strains no. 169, 176, and 100552 were repeatedly tested against group $A$ to $U$ diagnostic antisera. Positive precipitation reaction was not obtained, nor did we find a group-specific substance compatible with groups A to U.

In addition, the above-mentioned extracts were tested against groups $B$ and $F$ typing antisera $(8-11,16)$; no cross-reactivity was found.

Heat-killed whole cells of Streptococcus strains no. 169,176 , and 100552 produced homologous antibodies in rabbits. The antigenantibody systems of strains no. 169,176, and 100552 precipitated crosswise (Fig. 1). Antisera to strains no. 169,176 , and 100552 gave no positive precipitation reaction with any of the reference strains of groups $A$ to $U$.

The antigenic component responsible for the homologous group reaction was not destroyed by proteolytic digestion with trypsin or pepsin. The respective antigens were also prepared by the formamide method. Therefore, we presume the antigens to be polysaccharide in nature.

Absorption experiments. The evidence for distinction of the system of antigens and antibodies of strains no. 169,176 , and 100552 from the systems of antigens and corresponding group-specific antibodies of all the known serological groups was corroborated by crossabsorption experiments, performed as follows. Small volumes of anti-169, anti-176, and anti-100552 sera were absorbed with heat-killed packed group A to U streptococci and the homologous immunization strains no. 169, 176, and 100552. Antibodies to strains no. 169, 176 , and 100552 were not absorbed by any of the reference grouping strains. Absorption by the homologous strains, on the other hand, removed the precipitating antibodies quantitatively (Fig. 2). Another cross-absorption experiment involved absorbing small volumes of 

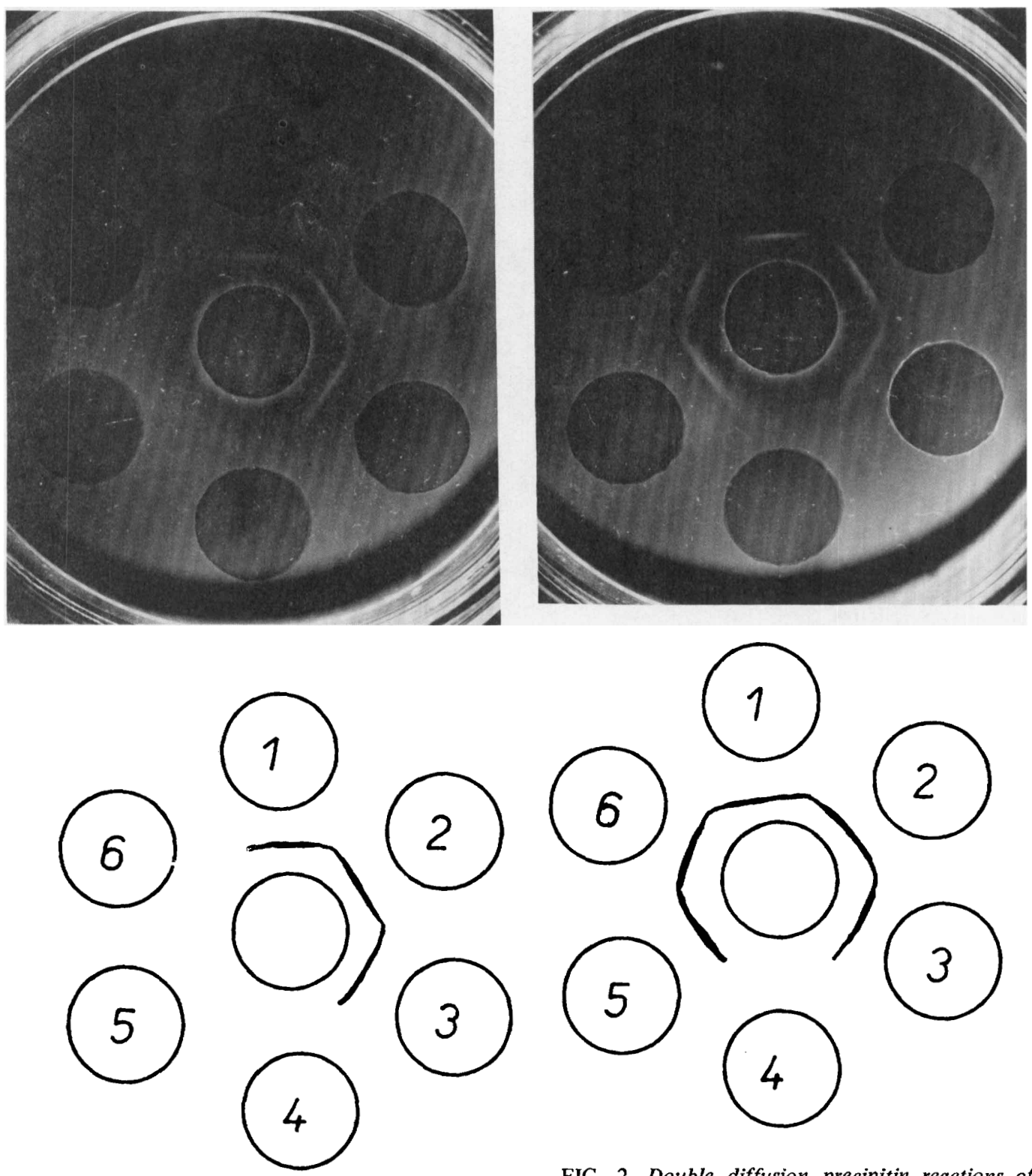

FIG. 2. Double diffusion precipitin reactions of group " $V$ " antiserum, prepared with strain no. 176 (peripheral wells). Effect of absorption with heterolog.

FIG. 1. Double diffusion precipitin reactions of group " $V$ " antiserum, prepared with strain no. 176 (center well). The identity of group antigens of individual group " $V$ " strains no. 176 (well 1), 169 (well 2), and 100552 (well 3). Negative reactions with reference antigens of group $E$ (well 4 ), group $P$ (well 5), and group $U$ (well 6). Antigens prepared by Fuller's method (5). ous group B cells (well 1), group E cells (well 2), group $P$ cells (well 5), and group $U$ cells (well 6); absorption with homologous no. 176 cells (well 4). Heterologous group cells did not absorb the antibodies; homologous no. 176 cells removed the antibodies. Control: unabsorbed " $V$ " antiserum (well 3). Center well contains the homologous antigen no. 176, prepared by Fuller's method (5). 
group-specific diagnostic sera $A$ to $U$ with strains no. 169,176 , and 100552 . No absorption of antibodies in the $\mathrm{A}$ to $\mathrm{U}$ grouping sera was obtained.

On the basis of the evidence presented here, we regard strains 169,176 , and 100552 as belonging to a new serological group of hemolytic streptococci, for which we propose the designation "V."

\section{ACKNOWLEDGMENTS}

We thank W.R. Maxted of the Public Health Laboratory Service, London, and R. R. Facklam of the Center for Disease Control, Atlanta, Ga., for their help in the reexamination of the strains studied in their laboratories. This was realized during the "Exchange of Research Workers Grant" that one of us (J.J.) was awarded by the World Health Organization in 1973 .

We are grateful to $E$. Thal of the National Veterinary Institute, Stockholm, for providing us with his group $U$ streptococcus strains and reference group $\mathrm{U}$ antisera, and for the reexamination of our materials in his laboratory.

We wish to thank J. Rotta, WHO International Reference Center for Streptococcus Typing, Prague, for his support.

The excellent laboratory assistance of J. Motlová of the Department of Medical Microbiology, Postgraduate Medical and Pharmaceutical Institute, Prague, Czechoslovakia is much appreciated.

\section{REPRINT REQUESTS}

Address reprint requests to: Dr. J. Jelínková WHO International Reference Center for Streptococcus Typing, Institute of Hygiene and Epidemiology, 48 Srobárova, 10042 Prague, Czechoslovakia.

\section{LITERATURE CITED}

1. Christie, R., N. E. Atkins, and E. Munch-Petersen. 1944. A note on a lytic phenomenon shown by group B streptococci. Aust. J. Exp. Biol. Med. Sci. 22:197-200.

2. de Moor, C. E. 1963. Septicaemic infections in pigs, caused by haemolytic streptococci of new Lancefield groups designated R, S and T. Antonie van Leeuwenhoek J. Microbiol. Serol. 29:272-280.

3. de Moor, C. E., and E. Thal. 1968. Beta haemolytic streptococci of the Lancefield groups E, P and U: Streptococcus infrequens. Antonie van Leeuwenhoek J. Microbiol. Serol. 34:377-387.

4. Facklam, R.-R. 1972. Recognition of group D streptococcal species of human origin by biochemical and physiological tests. Appl. Microbiol. 23:1131-1139.

5. Fuller, A. T. 1938. Formamide method for extraction of polysaccharides from haemolytic streptococci. Brit. J. Exp. Pathol. 19:130-139.

6. Hahn, G., W. Heeschen, and A. Tolle. 1970. Streptococcus-Eine Studie zur Struktur, Biochemie, Kultur und Klassifizierung. Kieler Milchwirtschaftl. Forschungsberichte 22:333-546.

7. Lancefield, R. C. 1933. A serological differentiation of human and other groups of haemolytic streptococci. J. Exp. Med. 57:571-595.

8. Lancefield, R. C. 1934. Serological differentiation of specific types of bovine hemolytic streptococci (group B). J. Exp. Med. 59:441-458.

9. Lancefield, R. C. 1938. Two serological types of group B hemoly tic streptococci with related, but not identical, type-specific substances. J. Exp. Med. 67:25-40.

10. Ottens H., and K. C. Winkler. 1962. Indifferent and haemolytic streptococci possessing groupantigen F. J. Gen. Microbiol. 28:181-191.

11. Pattison, I. H., P. R. J. Matthews, and D. G. Howell. 1955. The type classification of group B streptococci, with special reference to bovine strains apparently lacking in type polysaccharide. J. Pathol. Bacteriol. 69:51-60.

12. Raška, K., and J. Rotta. 1967. Streptococcal infections and their sequelae. Monograph, Avicenum, Prague.

13. Rotta, J. 1970. Group identification of haemolytic streptococci. Draft, WHO International Reference Center for Streptococcus Typing, Prague.

14. Thal, E., and G. Obiger, 1969. Das CAMPPhänomen des Streptococcus agalactiae und der neuen serologischen Streptokokken-gruppe "U" sowie weiterer Bakterienarten. Tierärtzl. Wochenschr. 82:126-130, Berlin, Hamburg.

15. Thal, E., and O. Söderling. 1966. Ny serologisk grup ("U") av beta-hämolyserande streptokokker isolerade fran svin, p. 336-339. Nord. Proc. Vet. Med. Cong., Stockholm.

16. Wilkinson, H. W., and R. G. Eagon. 1971. Type-specific antigens of group B type Ic streptococci. Infect. Immunity 4:596-604. 